Article

\title{
Education for Sustainability and the Sustainable Development Goals: Pre-Service Teachers' Perceptions and Knowledge
}

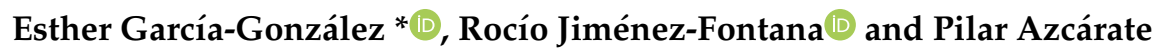 \\ Faculty of Education, Universidad de Cádiz, Puerto Real, 11519 Cádiz, Spain; rocio.fontana@uca.es (R.J.-F.); \\ pilar.azcarate@uca.es (P.A.) \\ * Correspondence: esther.garcia@uca.es; +34-956-016259
}

Received: 24 June 2020; Accepted: 15 September 2020; Published: 18 September 2020

check for updates

\begin{abstract}
The purpose of this study is to explore the change in the perceptions of pre-service teachers after participating in a training process on Education for Sustainability. The research was conducted during academic year 2019-2020 in the context of the Master's Degree in Educational Research for Teachers' Professional Development. The changes related to Education for Sustainability, the knowledge of the Sustainable Development Goals, and methodological strategies to integrate both were analysed. An initial and a final questionnaire as well as the activities developed by the students during the course were used to gather information. An analysis was performed of three dimensions (Education for Sustainability, the Sustainable Development Goals, and methodological strategies) with the help of the NVivo 12 Plus software programme. The results show progress was made in all three dimensions. The most significant changes were detected with regard to the knowledge of the Sustainable Development Goals, and the majority of the student teachers indicated they knew them on completing the training process. Their perception of Education for Sustainability evolved towards more complex views, while the methodological strategies proposed at the end of the training process did not differ significantly from the initial ones. This shows it is imperative to insist on training processes that include methodological strategies. By doing so, future educational professionals will be able to incorporate Education for Sustainability into their teaching practice.
\end{abstract}

Keywords: Education for Sustainability; the SDGs; students' perceptions; strategies to integrate Education for Sustainability

\section{Introduction}

Education is usually called upon when societies are supposed to improve the conditions associated with their well-being. New designs and the implementation of significant changes are put forward [1]. The United Nations Educational, Scientific and Cultural Organization (UNESCO) [2] proposes Education for Sustainability (hereinafter referred to as EfS) to act in complex circumstances such as the current situation of planetary emergency [3] in a sustainable manner.

The role of education is to ensure that all students acquire the theoretical and practical knowledge necessary to promote sustainable development by the year 2030. Logically, this transformation towards EfS approaches requires the commitment of teachers and researchers through effort, motivation, and innovative ideas [4]. To respond to said commitment, teacher training is faced with the challenge of training sensible, creative, and proactive professionals who think critically. The aim of EfS is not only for students to be successful in their future careers, it also seeks to provide them with skills, motivations, and a scale of values with which to contribute to the well-being of the global community [5].

It is necessary to empower individuals through competencies that encourage reflection on their own actions, taking into account the effects in different spheres and at different scales. Universities, 
responsible for the training of future professionals, must adapt to the needs that arise in society, and those future teachers must perform their work from the perspective of sustainability [6].

Teachers are in charge of preparing the coming generations to face the challenges of current unsustainable development. They also play a role in shaping the future $[7,8]$. This requires the participation of different disciplines and teachers need to have comprehensive and profound knowledge of the global situation [9]. Integrating the principles of EfS in teacher training is therefore crucial. Teachers' ideas and perceptions are decisive when it comes to putting in place adequate EfS [10]. They are crucial for teachers to develop the necessary skills to incorporate EfS into their classroom practice [11]. Teachers' perceptions of EfS contribute significantly to how they teach and prepare their students for the future [12]. Their worldviews determine their teaching practice [13].

Due to its complex and normative nature, sustainability requires the participation of different stakeholders such as scientists who cooperate across disciplines to find new solutions to problems related to sustainability [8]. However, for the most part, people are consumers of already formulated scientific ideas that include aspects such as opinions, beliefs, perceptions, and conceptions [14]. These gain importance when they become that on which individuals build practices and establish more or less ambitious objectives of change [14] with regard to certain environmental problems or the environmental crisis in general. Likewise, the perceptions associated with sustainability and EfS usually separate environmental from economic perspectives, and the social aspects or the relationship between ecological and social problems [15] are hardly ever taken into account [12]. Considering the above, it seems relevant to clarify what perceptions pre-service teachers have of sustainability and EfS in order to design training processes that take on the challenge of making these perceptions evolve from reductionist and fragmented views towards more complex and advanced stages. That is, from a holistic point of view orientated towards action in the environment, in accordance with the characteristics attributed to sustainability in several studies $[16,17]$.

After the United Nations Conference on Sustainable Development (Rio + 20), EfS adopts the guidelines of the 2030 Agenda for Sustainable Development [18]. Those guidelines shape a global framework to redirect humanity towards a sustainable path. It is the most ambitious global agenda approved by the international community to mobilise collective action around common goals, proposing systemic responses to a global and interrelated view of sustainable development [19].

The 17 Sustainable Development Goals (hereinafter referred to as the SDGs), which are universal, transformative, and inclusive, are part of the 2030 Agenda and describe the main challenges of development for humanity [2]. These goals convert the search for sustainable development into actions and become an appropriate strategy for working on EfS in the classroom.

In Spain, the SDGs are gaining ground. Their presence in university teaching practices [15] has been analysed as well as their learning content, which is in tune with active learningteaching strategies, and the development of competencies in sustainability for future teachers [20]. Although the knowledge student teachers have of the SDGs [21] has not been studied in depth, there are incipient studies that address this issue [22].

In this regard, the knowledge and understanding of the SDGs and their implications in the classroom are vital to connect teachers' perceptions and promote integration and connections with the principles of EfS.

Setting out on the path of sustainability requires a profound transformation in the way people think and act. To create a more sustainable world and address issues related to the SDGs, individuals must be agents of change. They need knowledge, skills, values and attitudes that empower them to contribute to sustainability $[16,17,23,24]$. The 2030 Agenda itself establishes that by the year 2030 it will ensure that "all learners acquire the knowledge and skills needed to promote sustainable development, including, among others, through education for sustainable development and sustainable lifestyles, human rights, gender equality, promotion of a culture of peace and non-violence, global citizenship, and appreciation of cultural diversity and of culture's contribution to sustainable development" [18] (p. 17). 
Education is therefore considered to be a crucial element to achieve this kind of development. Although there are many ways to integrate sustainability into teacher training [9], not all kinds of education promote sustainable development [2]. The transformation of competencies into sustainability of both the individual and society requires a holistic learning process that addresses the cognitive, socio-emotional, and behavioural domains of learning in a balanced way [8].

There is a broad consensus among experts that EfS requires active, participatory, and experimental learning methods that involve students and make a real difference for their understanding and ability to act. Those ideas are based on the assumption that preparing students to manage emerging sustainability issues such as climate change, loss of biodiversity, and growing social inequality require new ways of teaching and learning [25]. Integrating the SDGs from this perspective requires knowing methodological strategies that advocate sustainability [26] and having the necessary skills [11]. To that end, training in strategies that promote the global integration of knowledge, resources, and actions to work on EfS in their future teaching practice should be promoted. Previous studies [12] show that the strategies student teachers are using to integrate EfS are limited.

In conclusion, working on EfS may influence future teachers' development of key competencies that are relevant for the understanding of the SDGs. It may also determine the specific learning outcomes necessary to achieve a given SDG. Also, vice versa, understanding the scope of the SDGs can facilitate the development of adequate EfS [2]. The SDGs may be a way to understand EfS [27], as well as a useful tool to include it in the classroom. While many research studies focus on characterising competencies in sustainability and discuss general pedagogical approaches, so far there are very few papers investigating the links between common teaching and learning formats in EfS, factors in student learning processes that hinder or support learning, and the actual achievement of expected learning outcomes [28,29].

\section{Study and Research Questions}

The present study is an in-depth analysis of student perceptions and knowledge of EfS and the SDGs in the course Equity and Sustainability of the Master's Degree in Educational Research for Teachers' Professional Development at the University of Cádiz. The main objective of the course was to provide Education for Sustainability.

This study therefore focuses on exploring the change in pre-service teachers' perceptions of EfS after participating in a training process on Efs. The process addresses specific aspects that make up EfS such as its relationship with the SDGs and methodological strategies.

Taking the definition of the problem as a starting point, the research questions are formulated as follows:

- What progress is observed in the students' perceptions of EfS?

- How does student knowledge of the SDGs evolve?

- Do the strategies proposed by the students to integrate EfS and the SDGs into their teaching practice change after the training process?

\section{Context and Participants}

The research was carried out during academic year 2019-2020 at the University of Cádiz within the context of the Master's Degree in Educational Research for Teachers' Professional Development, in the course Equity and Sustainability in the Ideal School.

The training process developed a participatory process based on constructivism, which consisted of seven sessions of two hours each. Its purpose was to train students in EfS and the SDGs. To do this, three areas of study were addressed throughout the process: EfS, the SDGs, and strategies to integrate both in practice. 
The training process was structured in three phases that combined individual and cooperative work:

- Initial phase. Introduction and characterisation of the global crisis. The students filled out an individual questionnaire that addressed, amongst others, the different spheres indicated.

- Intermediate phase. Working for a better world. In this phase, the students worked together in groups of 4 to 6 members. First, they developed a pictogram to diagnose current issues and their interactions. Then, they were organised into six groups in which the students worked cooperatively: They analysed the meaning of EfS and the SDGs. They prepared a report using the Aronson's jigsaw strategy on the meaning and scope of EfS. Aronson's jigsaw technique is a cooperative learning strategy. Students are put into groups to work on a topic. The teacher gives them as many documents on the subject under study as there are members in the group. All documents are different. Each of the group members will be responsible for reading and analysing one of the documents. Once this is done, the members of the different groups that are dealing with the same document form expert groups to discuss it. Then, the members return to their initial group where they present the main ideas to the rest of the group. In this way, knowledge about the subject of study is built through different interactions. They discussed the variety of methodological strategies that promote the inclusion of EfS in the classroom. They analysed and compared educational proposals. Finally, they designed a didactic proposal from the perspective of EfS in which they had to include the SDGs.

- Final phase. Assessment. The students completed the same initial individual questionnaire to which a general assessment question was added.

A total of 32 students, 7 male students and 25 female students, aged 22 to 29, participated in the training process. They are all graduates in Primary Education or Early Childhood Education.

\section{Data Collection and Analysis}

From a qualitative perspective, to understand the phenomenon under study in a contextualized manner, it is necessary to use techniques that range from the observation of reality to the analysis of oral and written narratives or the study of written documents [30]. In this case, the activities developed by the participants during the course were chosen. They reflect their perceptions and knowledge, which are analysed from an interpretive approach.

During the three phases of the course, described in the previous section, different activities were developed. Of all the activities developed in the course, for this research, four were selected for data collection. They were directly related to the research questions and were previously designed for that purpose:

- Initial questionnaire (IQ), of open-ended questions adapted from previous [9] (Figure 1). Of the eight IQ ones, the ones used in this research were:

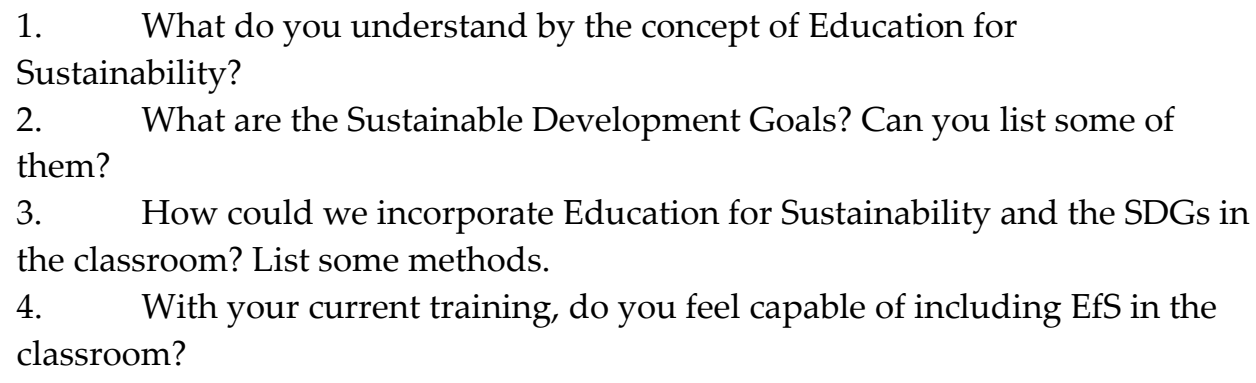

Figure 1. Initial questionnaire. 
- Report on EfS (REfS).

- Design of a sequence of activities to include the SDGs in the classroom training processes (SA).

- Final questionnaire (FQ). To the questions asked in the initial questionnaire, an assessment question was added: provide your final thoughts about what the course content has offered you. To you, what has been the most significant contribution of the course?

With regard to question 4 of the initial and final questionnaire, it was aimed to promote students' reflection on their own training. It was intended to serve as complementary information to the results obtained for the dimension Knowledge of strategies for the inclusion of EfS and the SDGs (Table 1). Those answers have not been included in the total number of units of information (UIs) since they are only complementary information inserted in the presentation of results for said dimension.

In order to process the data, they were reduced to meaningful units of information. A system was developed for the analysis (Tables 1 and 2). The first step was to formulate three dimensions related to the research questions for the analysis. They arose from theory and were predefined and agreed upon by the researchers. The dimensions respond to the purpose of the process itself, training in EfS. It is therefore necessary to know what EfS means to the students [12]. Also, in relation to this, it is essential to find out what they know about the SDGs and, especially, what they know about the teaching strategies to integrate EfS in their future teaching practice. Those aspects were already considered relevant in previous studies $[9,31,32]$.

The analysis dimensions put forward were:

- Dimension 1: Perceptions of EfS.

- Dimension 2: Knowledge of the SDGs.

- Dimension 3: Knowledge of strategies for the inclusion of EfS and the SDGs.

Once the dimensions were defined, the second step was to establish a series of levels, which also arose from the theory, that described those dimensions. The levels were formulated at different degrees of complexity. The third step consisted of carrying out a comparison between the previous levels from the theory and the data (pilot test) to adjust the formulation of these levels to the reality of the analysis [33]. The first proposal of the analysis system was subjected to a triangulation process between the team of researchers and three experts in EfS who analysed the proposal and the levels formulated. After performing triangulation, the definitive analysis system was configured (Table 1).

For the analysis, each unit of information (hereinafter referred to as UI) was associated with a dimension and a level of the analysis system and they were treated globally. The NVivo 12 Plus software was used through which the coding matrices were obtained that allowed the frequencies to be extracted and the results to be organised.

Encoding of the units of information was as follows:

- $\mathrm{S}+\mathrm{n}$ : information coming from a student. A number was assigned to each of them.

- $\mathrm{G}+\mathrm{n}$ : information coming from a group. A number was assigned to each of them.

In addition, the data collection instrument the UIs came from was specified: IQ, REfS, SA, or FQ. An example of final encoding would be: S1_FQ. 
Table 1. Definitive analysis system.

\begin{tabular}{|c|c|c|c|}
\hline Level & D1: Perceptions of EfS & $\begin{array}{l}\text { D2: Knowledge of the } \\
\text { SDGs }\end{array}$ & $\begin{array}{l}\text { D3: Knowledge of the Strategies } \\
\text { for the Inclusion of EfS and the } \\
\text { SDGs }\end{array}$ \\
\hline 0 & $\begin{array}{l}\text { Vague answer. They refer to } \\
\text { education but not in relation to } \\
\text { sustainability. }\end{array}$ & $\begin{array}{l}\text { They are not familiar with } \\
\text { them. }\end{array}$ & $\begin{array}{l}\text { They do not know/They have no } \\
\text { opinion }\end{array}$ \\
\hline 1 & $\begin{array}{l}\text { Education for the conservation of } \\
\text { the environment and natural } \\
\text { resources. Related to a naturalist } \\
\text { definition of sustainability [34] and } \\
\text { based on the limits of growth [35]. }\end{array}$ & Their knowledge is vague. & Traditional didactic approaches \\
\hline 2 & $\begin{array}{l}\text { Education for the conservation of } \\
\text { the natural environment and social } \\
\text { or economic improvement. } \\
\text { It involves education for } \\
\text { sustainability focusing on the } \\
\text { natural environment, but } \\
\text { recognising the importance of the } \\
\text { other spheres of sustainability } \\
\text { without integrating the three of } \\
\text { them [36]. }\end{array}$ & $\begin{array}{l}\text { They know them and specify } \\
\text { them. At this level, they are } \\
\text { classified by their nature } \\
\text { based on an adaptation of } \\
\text { Albareda-Tiana et al. [15] in: } \\
\text { Environmental, Social and } \\
\text { Economic spheres (see } \\
\text { Table 2) }\end{array}$ & $\begin{array}{l}\text { Vague descriptions/intentions, no } \\
\text { answers are provided. Idealistic. }\end{array}$ \\
\hline 3 & $\begin{array}{l}\text { Education including the spheres of } \\
\text { sustainability }[37,38] \text {. }\end{array}$ & & $\begin{array}{l}\text { Specific resources or actions [6] } \\
\text { that are not integrated into a } \\
\text { global methodology [39]. } \\
\text { For example, reading a news } \\
\text { article or discussing a topic. }\end{array}$ \\
\hline 4 & $\begin{array}{l}\text { Education including the three } \\
\text { spheres of sustainability. It concerns } \\
\text { a holistic and integrated approach } \\
\text { that stresses the development of } \\
\text { skills and competencies to apply } \\
\text { sustainability }[16,17] \text { and improve } \\
\text { quality of life [34]. }\end{array}$ & & $\begin{array}{l}\text { Active, participatory and } \\
\text { experimental learning methods } \\
\text { that involve the student and make } \\
\text { a real difference with regard to } \\
\text { understanding, thinking, the } \\
\text { commitment towards the } \\
\text { environment and the students' } \\
\text { capacity to act [32,40]. } \\
\text { They resemble constructivist } \\
\text { approaches [27]. They entail } \\
\text { restructuring subjects towards } \\
\text { holistic approaches. For example, } \\
\text { problem-based learning or case } \\
\text { studies [41]. }\end{array}$ \\
\hline
\end{tabular}

Table 2. Relationship between the spheres of sustainability and the Sustainable Development Goals (SDGs). Adapted from Albareda-Tiana et al. [15].

\begin{tabular}{lll}
\hline \multicolumn{1}{c}{ Environmental } & \multicolumn{1}{c}{ Social } & \multicolumn{1}{c}{ Economic } \\
\hline & SDG 2: Zero Hunger & \\
& SDG 3: Good Health and Well-Being & SDG 1: No Poverty \\
& SDG 4: Quality Education & SDG 8: Decent Work and \\
SDG 6: Clean Water and Sanitation & SDG 5: Gender Equality & Economic Growth \\
SDG 13: Climate Action & SDG 7: Affordable and Clean Energy & SDG 9: Industry, Innovation and \\
SDG 14: Life below Water & SDG 11: Sustainability Cities and & Infrastructure \\
SDG 15: Life on Land & Communities & SDG 10: Reduced Inequalities \\
& SDG 16: Peace, Justice and Strong & SDG 12: Responsible \\
& Institutions & Consumption and Production \\
& SDG 17: Partnerships for the Goals & \\
\hline
\end{tabular}

\section{Results}

The information obtained is organised by dimensions and the levels (henceforth L) that constitute them. The results for the three phases of the training process described in the Context and Participants 
section are included in each dimension. The total number of UIs was 457, of which 155 belonged to the initial phase, 90 to the intermediate phase, and 212 to the final one.

Different data collection instruments were used for each phase: An initial questionnaire (IQ) in the initial phase, two group reports prepared by the students (REfS and SA) in the intermediate phase, and a final questionnaire (FQ) in the final phase.

\subsection{Perceptions of EfS}

In the initial phase, as shown in Table 3, slightly more than half (53.1\%) of the UIs are found in L1. This shows the students have a perception of EfS, the purpose of which is caring for the environment and conserving natural resources. This is reflected in the words of S1_IQ: Provide students with values education so they become future citizens who take care of the environment so as not to accelerate changes in it. It also highlights that $28 \%$ of the UIs reflects students have a vague idea of the meaning of EfS, since they do not express relationships between education and sustainability. S7_IQ explains: It is about acquiring certain knowledge and ways of acting to perform actions that contribute to its proper development.

The UIs show there are no students who express a comprehensive and complex view of EfS in this initial phase.

In the intermediate phase, no UIs were identified for levels 0,1 , and 2 (Table 3). These results indicate the majority of the students have a perception of EfS that integrates the three spheres of sustainability, without referring to its potential to train students. An example is the one indicated by G2_ REfS: Education for Sustainability is an educational modality that promotes the balance between economic growth, conservation of the environment, cultural diversity and social welfare, taking into account marginalized populations and equality issues between men and women.

In this intermediate phase, the rest of the UIs (37.5\%) refer to a holistic view of EfS (L4). This is the case of G5_REfS: Based on these ideas, learning in this framework is not only conceived as the process of acquiring knowledge, values and theories related to sustainable development, but it also attaches great importance to the change of mentality and the active participation of students in issues related to a more sustainable future.

Finally, in the final phase, almost half of the UIs (47.5\%) were classified as L4. This level refers to a perception of EfS that integrates the three spheres of sustainability, and that provides the students with training for action. This is stated by S11_FQ: Education for sustainability allows every human being to acquire the knowledge, skills, attitudes and values necessary to be an active member in society. It concerns the four spheres of sustainability which are the environment, society, the economy and politics.

In L3, 22.5\% of the UIs were classified. An example is the response of S18_FQ: Education for sustainability suggests teaching students to think critically to make the world a fairer place, respect the environment and fight inequality. In L1, 20\% of the IU were classified and in L0, $10 \%$, which means that at the end of the process there were students who still had a vague idea of EfS, since they did not establish any links between education and sustainability. This is the case of S25_FQ: It consists in helping people to acquire attitudes and skills to make the decisions they consider appropriate for their benefit and that of others.

Table 3. Units of information (UIs) for the dimension of perceptions of Education for Sustainability (EfS).

\begin{tabular}{ccccccccccc}
\hline Level & \multicolumn{2}{c}{ L0 } & \multicolumn{2}{c}{ L1 } & \multicolumn{2}{c}{ L2 } & \multicolumn{2}{c}{ L3 } & \multicolumn{2}{c}{ L4 } \\
\hline & UIs & $\%$ & UIs & $\%$ & UIs & $\%$ & UIs & $\%$ & UIs & $\%$ \\
Initial phase & 9 & 28.1 & 17 & 53.1 & 3 & 9.4 & 3 & 9.4 & 0 & 0 \\
Intermediate & 0 & 0 & 0 & 0 & 0 & 0 & 5 & 62.5 & 3 & 37.5 \\
phase & 4 & 10 & 8 & 20 & 0 & 0 & 10 & 22.5 & 19 & 47.5 \\
Final phase & 4 & & & & & & & & &
\end{tabular}

\subsection{Knowledge of the SDGs}

Regarding the knowledge of the SDGs, in the initial phase, more than half of the UIs (53.1\%) reported on the students' lack of knowledge of the SDGs (Table 4). An example is the response of S16_IQ: I do not know what the Sustainable Development Goals are. In contrast, almost one-third of the 
UIs $(28.1 \%)$ indicate the students know them and even list some of them. This is the case of S22_IQ: The SDGs are those challenges that, put in common with the rest of the countries through an agreement, are intended to be achieved to combat some of the most significant problems of our planet such as reducing poverty, climate change and improving education, amongst others.

In the intermediate phase, $100 \%$ of the UIs were classified as L2, which means the students indicate they know what they are. This is the case of G3_SA: The SDGs shown in this situation are the following: Quality education, Responsible production and consumption, Underwater life and Life of terrestrial ecosystems.

At the end of the course, the majority of the UIs (84.4\%) show the students know the SDGs. S18_FQ points out: The SDGs are 17 objectives that aim to improve the world in which we live. They were established in 2015 and are related to the concept of sustainability. They are intended to have been achieved by the year 2030. Some of the objectives are: quality education, climate action, underwater life, end of poverty, health and well-being, amongst others.

Table 4. UIs for the dimension of knowledge of the SDGs.

\begin{tabular}{ccccccc}
\hline Level & \multicolumn{2}{c}{ L0 } & \multicolumn{2}{c}{ L1 } & \multicolumn{2}{c}{ L2 } \\
\hline & UIs & $\%$ & UIs & $\%$ & UIs & $\%$ \\
Initial phase & 17 & 53.1 & 6 & 18.8 & 9 & 28.1 \\
Intermediate & 0 & 0 & 0 & 0 & 6 & 100 \\
phase & 0 & 0 & 5 & 15.6 & 27 & 84.4 \\
Final phase & 0 & & & & &
\end{tabular}

In order to characterise the knowledge of the SDGs, those SDGs the students mentioned were classified by their nature and type in each of the phases (Table 5). An instrument used in previous studies was used for the classification [12].

In the initial phase, the UIs refer mainly to the SDGs of the social sphere, which account for $41.4 \%$. In these UIs, the most representative SDGs were SGD 4 (quality education) and SDG 16 (peace, justice and strong institutions). The economic sphere represents $31.2 \%$, SDG 1 (end of poverty) being the most frequently cited SDG in the UIs. The environmental sphere comes last obtaining $27.4 \%$. The SDGs mentioned the most in the UIs were SDG 14 (underwater life) and SDG 15 (life on land).

In the intermediate phase, the groups designed an educational proposal to work on the SDGs at school. In the proposals made, $40 \%$ of the SDGs included belong to the social sphere of sustainability, with SDG 4 being the most significant. The SDGs of the economic sphere represented $35 \%$ of the total and SDG 12 (responsible production and consumption) was the most representative one. The SDGs with the least representation were those of the environmental sphere $(25 \%)$, in which SDG 15 stood out above the others.

In the final phase, the social sphere was the most common one; $50.8 \%$ of the UIs referred to it. In this sphere, the most represented SDGs are 4 and 3 (health and well-being). In the economic sphere, SDG1 (end of poverty) and SDG 12 are found.

It is noteworthy that in this last phase, all the SDGs are present in the UIs. 
Table 5. Nature and type of SDG.

\begin{tabular}{|c|c|c|c|c|c|c|c|c|c|c|c|c|c|}
\hline \multirow[t]{2}{*}{ Sphere } & \multicolumn{2}{|c|}{ Initial Phase } & \multicolumn{2}{|c|}{ Intermediate Phase } & \multicolumn{2}{|c|}{ Final Phase } & \multirow[t]{2}{*}{ SDGs } & \multicolumn{2}{|c|}{ Initial Phase } & \multicolumn{2}{|c|}{ Intermediate Phase } & \multicolumn{2}{|c|}{ Final Phase } \\
\hline & UIs & $\%$ & UIs & $\%$ & UIs & $\%$ & & UIs & $\%$ & UIs & $\%$ & UIs & $\%$ \\
\hline \multirow{3}{*}{ Environmental } & \multirow{3}{*}{8} & \multirow{3}{*}{27.4} & \multirow{3}{*}{5} & \multirow{3}{*}{25} & \multirow{3}{*}{15} & \multirow{3}{*}{21.6} & SDG 6 & 1 & 3.4 & 1 & 5 & 3 & 4.3 \\
\hline & & & & & & & SDG 13 & 1 & 3.4 & 1 & 5 & 5 & 7.2 \\
\hline & & & & & & & SDG 15 & 3 & 10.3 & 2 & 10 & 2 & 2.9 \\
\hline \multirow{8}{*}{ Social } & \multirow{8}{*}{12} & \multirow{8}{*}{41.4} & \multirow{8}{*}{7} & \multirow{8}{*}{40} & \multirow{8}{*}{35} & \multirow{8}{*}{50.8} & SDG 2 & 2 & 7 & 1 & 5 & 4 & 5.8 \\
\hline & & & & & & & SDG 3 & 1 & 3.4 & 1 & 5 & 7 & 10.1 \\
\hline & & & & & & & SDG 4 & 3 & 10.3 & 5 & 25 & 7 & 10.1 \\
\hline & & & & & & & SDG 5 & 2 & 7 & 0 & 0 & 4 & 5.8 \\
\hline & & & & & & & SDG 7 & 0 & 0 & 0 & 0 & 4 & 5.8 \\
\hline & & & & & & & SDG 11 & 1 & 3.4 & 1 & 5 & 3 & 4.4 \\
\hline & & & & & & & SDG 16 & 3 & 10.3 & 0 & 0 & 3 & 4.4 \\
\hline & & & & & & & SDG 17 & 0 & 0 & 0 & 0 & 3 & 4.4 \\
\hline \multirow{4}{*}{ Economic } & \multirow{4}{*}{9} & \multirow{4}{*}{31.2} & \multirow{4}{*}{7} & \multirow{4}{*}{35} & \multirow{4}{*}{19} & \multirow{4}{*}{27.6} & SDG 1 & 6 & 21 & 1 & 5 & 5 & 7.2 \\
\hline & & & & & & & SDG 8 & 1 & 3.4 & 1 & 5 & 3 & 4.4 \\
\hline & & & & & & & SDG 9 & 0 & 0 & 0 & 0 & 3 & 4.4 \\
\hline & & & & & & & SDG 10 & 1 & 3.4 & 2 & 10 & 3 & 4.4 \\
\hline
\end{tabular}




\subsection{Knowledge of Strategies for the Inclusion of EfS and the SDGS}

In the initial phase of the subject, $50 \%$ of the students indicated they did not feel able to include EfS in their teaching practice. This is reflected in the words of S10_IQ: At present, I consider I am not able to address the Sustainable Development Goals in the classroom, since I have not acquired proper training in Education for Sustainability. Twenty-five percent of the students pointed out they felt able to address them, S25_IQ: Yes, I could perfectly work on those goals in my classroom, adapting them to the ages of the little ones. Another $25 \%$ did not know or did not answer the question.

Despite the fact that $50 \%$ of the students did not think they were ready to integrate EfS, they did intuitively know ways of including it, and they proposed strategies (Table 6). In L3, which refers to the use of specific resources, $52 \%$ of the options (UIs) proposed by the students were classified. S28_IQ suggested: excursions for students to appreciate and get to know different social, cultural and natural spaces.

Furthermore, $23.3 \%$ of the UIs were classified as level 4, the most complex one. An example for this level is the one mentioned by S4_IQ: Through research projects that give rise to a product that favours sustainability. For example, the construction of a house or its plan that contains elements allowing the use of renewable energy.

In the intermediate phase, the UIs describe specific resources or actions such as debates or watching theme-based videos. G3_REfS put forward: Discussing current societies: production and consumption models. G6_REfS suggested: stimulus-based activities (watching a video or observing photographs). They also presented some ideas that were idealistic or that did not materialize in actions (representing 26.7\%). This is the case of one of the ideas expressed by G2_REfS: Encouraging children to think critically about all its aspects.

In the final phase of the process, $68.7 \%$ of the students indicated they felt capable of integrating the SDGs in their teaching practice. This is what S15_FQ stated: Taking into account I specialised in Early Childhood Education and after attending the sessions of this course, I do consider myself able to deal with the SDGs in the classroom. Twenty-five percent said they needed more training and $6.3 \%$ felt unable to do it even after completing the course.

In the final phase, the UIs mainly referred to specific actions to integrate sustainability such as those proposed by S31_FQ: Talks in the classes about pollution, or S12_FQ: Using audiovisual resources. Thirty-eight percent of the UIs was related to active learning methods promoting the students' capacity to act, as described by S25_FQ: Problem-based learning could be one of them, since it promotes direct links with reality. It allows detecting real problems, encourages debate, joint reflection or the search for solutions. All these opportunities pave the way for the development of critical thinking.

Table 6. UIs for the dimension of knowledge of strategies for the inclusion of EfS.

\begin{tabular}{ccccccccccc}
\hline Level & \multicolumn{2}{c}{ L0 } & \multicolumn{2}{c}{ L1 } & \multicolumn{2}{c}{ L2 } & \multicolumn{2}{c}{ L3 } & \multicolumn{2}{c}{ L4 } \\
\hline & UIs & $\%$ & UIs & $\%$ & UIs & $\%$ & UIs & $\%$ & UIs & $\%$ \\
Initial phase & 3 & 1.6 & 4 & 6.7 & 10 & 16.7 & 31 & 51.7 & 14 & 23.3 \\
Intermediate & 0 & 0 & 3 & 5 & 16 & 26.7 & 28 & 45 & 13 & 23.3 \\
phase & 0 & 0 & 3 & 4 & 7 & 10 & 35 & 48 & 28 & 38 \\
Final phase & 0 & & & & & & & & &
\end{tabular}

\section{Discussion}

The discussion of the results is organised around the research questions. The synthesis of the information obtained reflecting the progress observed is presented in each of the questions.

\subsection{What Progress Is Observed in the Students' Perceptions of EfS?}

Pre-service teachers' perceptions of EfS play a key role in the way they teach and prepare their students for the future [12]. Knowing and studying them can serve as a starting point for research in this field or for the design of training processes in EfS. Figure 2 shows the progress in the perceptions 
of the students participating in the study on EfS throughout the training process. In the initial phase, a perception of EfS related to caring for the environment and conserving natural resources prevails. This perception, which could be considered deficient for future educational professionals, is in line with the perceptions of university students found in previous studies [42,43]. This could be due to the fact that EfS is not usually addressed in initial teacher training, as shown by the lack of competencies in sustainability in curricula [44]. Nonetheless, a growing number of research studies reveals EfS is essential to achieve a sustainable present and future [20]. As the training process progressed, this perception became more complex. In the intermediate phase, the results show that most of the students integrated the three spheres of EfS, and part of the students also identified its holistic and integrated approach, which stresses the students' development of competencies (L4). This perception is also the one that most students manifest at the end of the training process, as observed in the results. This view is in accordance with the one that future teachers should have [45,46], and with the need for it to address the complexity intrinsic to EfS [47].

However, it cannot be ignored that levels 0 and 1 remain present in the final phase. In other words, there are students who maintain a vague or environmental perception of EfS. This is an incomplete perception of EfS, in which not all the spheres of sustainability are integrated [48]. Those results in which a comprehensive idea of EfS prevails, but environmental or limited ideas continue to exist after a training process that focuses on EfS, coincide with the results of similar research $[47,49]$.

Finally, the results show the role group work and interaction with the information provided during the process has played. Both served as a bridge toward a more complex view of EfS. It was diluted, in part, when the students reached the end of the process and it was observed that the first levels had persisted. However, it may be considered that group work favoured progress between the identified initial phase and the final one.

In general, and in keeping with other studies [49-51], it should be said that after the training process, the knowledge of the students regarding the meaning of EfS improved, since almost half of the IUs refer to holistic viewpoints oriented towards action in the environment, in accordance with the characteristics attributed to it in several studies [16,52]. A strong influence of the joint discussion process is observed. It allowed students to share ideas with their peers, contrast them, and evolve in their perceptions. This is observed in a higher level of complexity shown in the results that were obtained from group work. Although those levels of complexity were less present in the final phase, considerable progress was seen after the initial phase. This result further explores the idea of the importance of promoting cooperative learning in training processes of this nature.

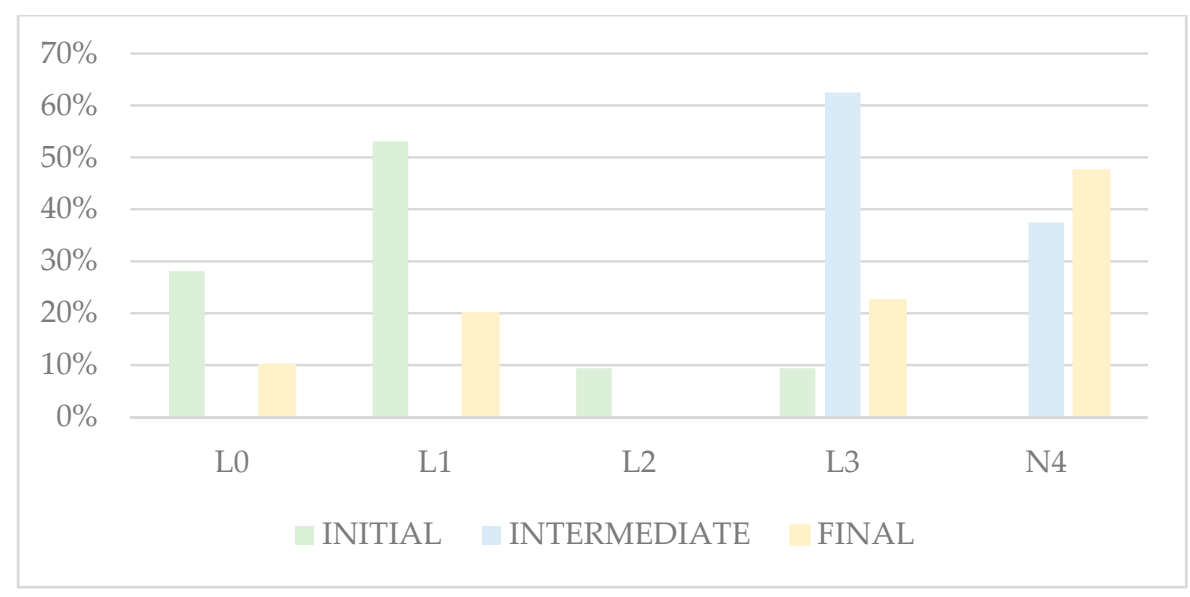

Figure 2. Progress in student perception of EfS. 


\subsection{How Does Student Knowledge of the SDGs Evolve?}

Given the inherent complexity of the concept of sustainability, the SDGs can contribute to its understanding [22,27]. They are also a useful tool for teachers to include EfS in the classroom. EfS evolves in line with emerging sustainability issues and challenges [53] referred to in the different SDGs [54]. Recent research [21], however, shows student knowledge of the SDGs is limited, and this is confirmed in the findings of this study. As Figure 3 shows, at the beginning of the training process, more than half of the UIs indicate the students did not know what the SDGs were. The 2030 Agenda and, as a result, the 17 SDGs, were adopted in 2015, but not all universities are incorporating them [55], since this topic remains largely unexplored [56]. Meanwhile, those who set out on the path of sustainability are doing it in different manners, depending on the educational institutions and degree programmes offered [57]. All this could affect the lack of student knowledge of the SDGs, in addition to what has been put forward in relation to the limited presence of EfS in their training.

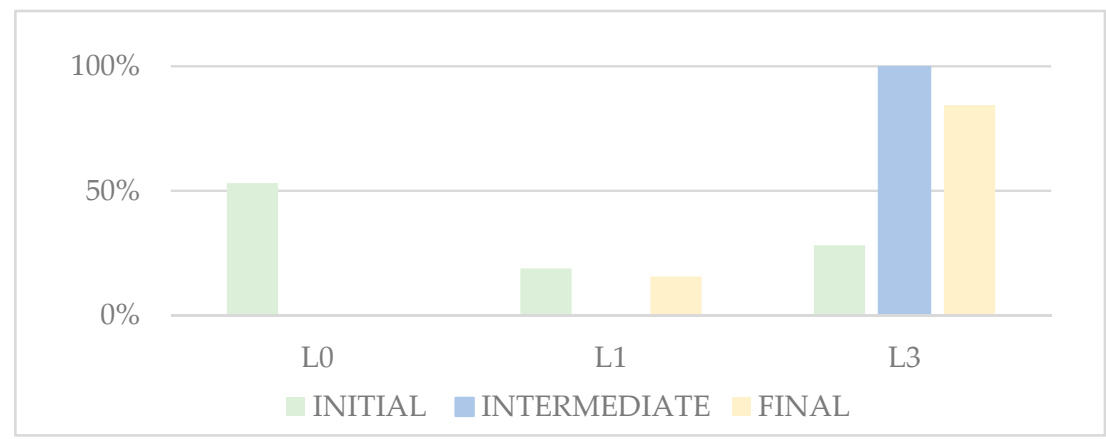

Figure 3. Development of knowledge of the SDGs.

Throughout the training process, the students acquired greater understanding of the meaning of the SDGs, and the UIs show that by the end of the process most students indicated they knew them (L3). Only a reduced number of students continued to have a vague idea of them. As in the previous dimension, group work was considered key in this change.

With the aim of deepening the knowledge the students had of the SDGs, an analysis of the nature and type of the SDGs was carried out.

The nature of the SDGs reflected in the UIs changed throughout the process (Figure 4). The environmental sphere is the least represented at the end of the process. Their knowledge of the economic and the social spheres increased. The latter is the predominant sphere in all phases. This could be due to the prior training of students, which prioritises social aspects. As described above, the students are all graduates in Primary Education or Early Childhood Education. The fact that the three spheres of sustainability are not balanced could be an impediment for the students to include sustainability in their teaching practice from a more integrating perspective. This is explored below, as these findings are directly related to the type of SDG indicated by the UIs.

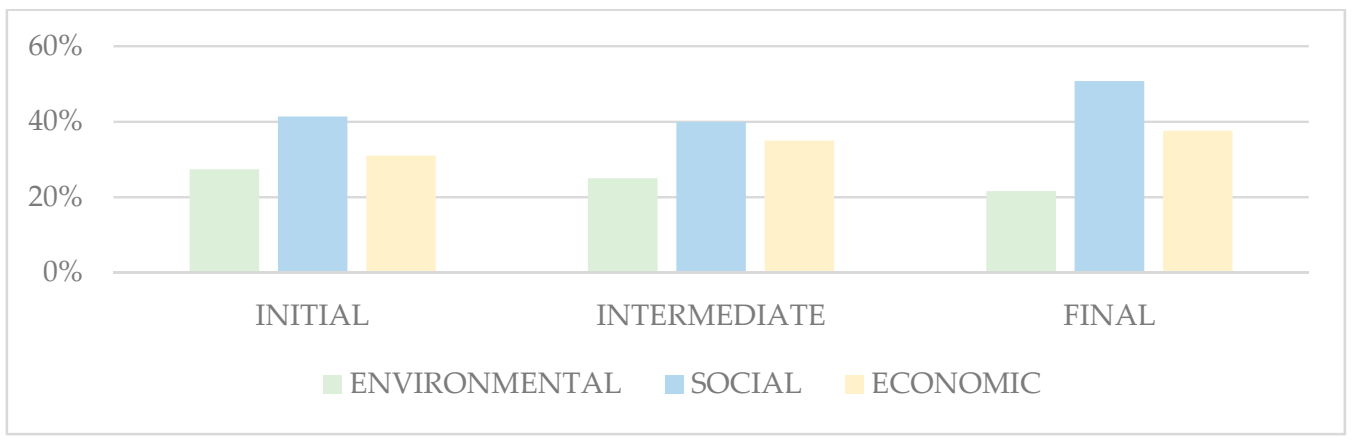

Figure 4. Nature of the SDGs. 
With respect to the types of SDGs present in the UIs (Figure 5), it is observed that at the beginning of the training process, SDG 7 (affordable and clean energy), SDG 9 (industry, innovation and infrastructure), or SDG 17 (partnerships for the goals) did not appear. Nor did the students use them when they designed their sequence of activities in the intermediate phase, as shown by the lack of UIs. SDG 5 (gender equality) and SDG 16 (peace, justice and strong institutions) were also lacking. In the final phase, all the SDGs appeared in the UIs.

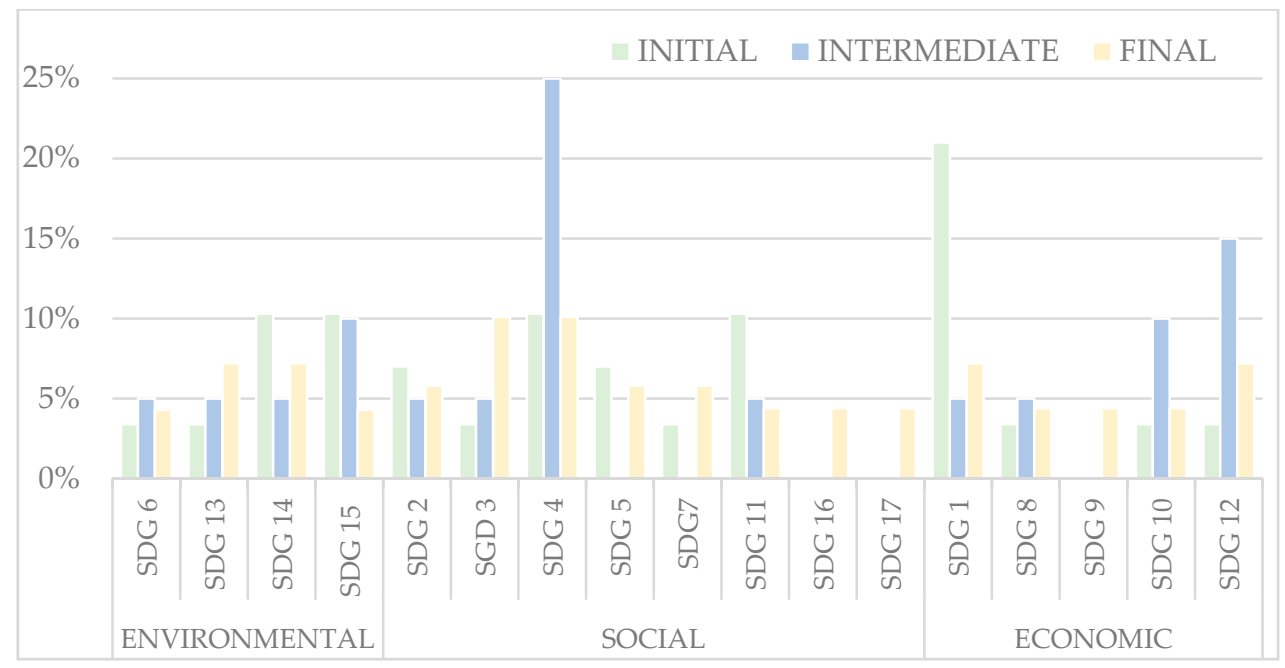

Figure 5. Development of knowledge of the SDGs.

Regarding the frequency with which the SDGs appeared, those classified as environmental, present in all three phases, also increased at the end with the exception of SDG 15 (life on land), which decreased. In the case of those of an economic nature, they appeared more often at the end, apart from SDG 1 (no poverty), whose presence was notably lower.

Finally, there was greater variability than in the previous cases for those SDGs of a social nature. It should be noted that SDG 4 (quality education) remained practically the same at the beginning and at the end of the training process, but during the intermediate phase its presence was stronger. This is probably because of the group work carried out during this phase in which the students considered the task itself was related to the improvement of education and their own role as educators. As in other studies [11], it was a matter of developing a didactic design that included the SDGs. It is important to highlight the relevance SDG 4 acquired during the process, as education is one of the main topics proposed by the United Nations to achieve sustainability [58].

The comparison drawn shows that at the end of the course, most of the students knew the SDGs and identified them all. This can be a stimulus for them to integrate sustainability in their classrooms in the future [59]. The SDGs provide pre-service teachers with numerous topics [39] related to the challenges of sustainability, which allow connecting them with real and current problems. This would encourage their future students to ask questions and explore issues in contexts relevant to themselves and to their communities [60].

Finally, it needs to be pointed out there is no balance as far as knowledge of the SDGs is concerned, since the SDGs of a social nature were the most representative and also the most numerous. It is therefore necessary to insist and work on the SDGs so that students acquire deeper knowledge of them. This has to be done from a view of sustainability that connects all its dimensions, which would help them integrate EfS from a holistic perspective. Addressing the SDGs without considering their interactions could cause a loss of their effectiveness [61] in building a fairer and more sustainable world. 
6.3. Do the Strategies Proposed by the Students to Integrate EfS and the SDGs into Their Teaching Practice Change after the Training Process?

The purpose of EfS is transformative. Working from this perspective and integrating the SDGs requires knowing methodological strategies that promote sustainability [26] and having the necessary skills for it [11]. This means future teachers require training to perform this task. In this regard, the participating students' perception of their own training improved between the beginning and the end of the training process.

When examining the strategies that the students would use to integrate EfS (Figure 6), it is observed that the presence of the first levels (L0-L2) of this dimension decrease as the process progresses and the students become familiar with the meaning of EfS. It is important to highlight that traditional methods (L1) such as lectures, which may pose an obstacle to the integration of EfS [31], are hardly present throughout the process. This aspect is encouraging, since most students do not consider using these methods in their future teaching practice and prefer others that are more in keeping with EfS, like problem-based learning (see Table 1, level 4, dimension 3). However, Figure 6 shows that traditional methods remain present until the end, since breaking away from the views that have been strongly structured during their training requires longer and more complex processes [62]. Their own teaching practice is likely to play an important role in the change of perspective.

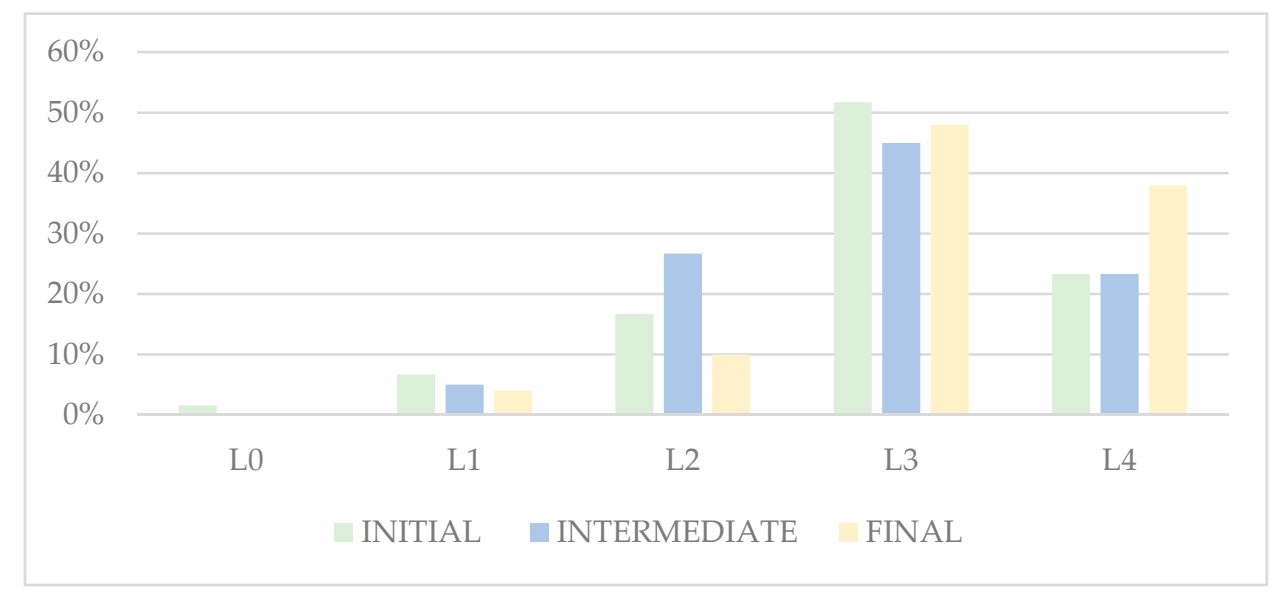

Figure 6. Change in the strategies the students propose.

With regard to L2, which alludes to vague or idealistic descriptions that do not translate into proposals, it is observed that in the intermediate phase, there is an increase in UIs of this kind with respect to the beginning of the course. This is possibly due to the fact that during the intermediate phase the students' idea of EfS becomes more complex thanks to group discussions, as shown in Figure 2. However, the students lack the pedagogical knowledge for its integration. Knowledge increases as the training process progresses, as the results obtained in L3 and L4 show. Another possibility is that the students focus on the action-oriented approach as they receive feedback from the teacher and from classmates.

L3 is the strongest level in all phases. Furthermore, its frequency is stable in all of them. This indicates the students' preference for specific actions or resources to integrate EfS, as seen in previous studies [6]. The strategies the students used are in tune with passive learning methods, for example watching a movie or having a debate [58]. This may lead to a partial or occasional integration of EfS and the SDGs in the classroom. If they are not part of a global methodological strategy, they may not develop their full transformative potential. The results obtained for this level also suggest that the students, even before working on the contents of the training process, intuitively knew a variety of ways to integrate EfS, which they had learned in previous training, but they did not acquire deep knowledge of them. 
Finally, a significant increase is observed in L4 at the end of the process. In this case, it concerns global strategies that imply a change in how the educational process is organised. Those strategies are widely used to integrate EfS $[31,32,41]$ without losing sight of the fact that recent studies stress the importance of conducting further research on their effectiveness because the existing empirical research in this field is still limited [25]. The most popular strategy of all the ones the students proposed was project work. They also underlined the research work focused on sustainability topics or community work. These are student-centred teaching and learning approaches in keeping with EfS [63], which offer students the possibility of developing critical thinking, connecting curriculum content with real life. Those approaches actively involve students in planning, monitoring, and assessing issues related to sustainability $[52,64,65]$.

In summary, the results reveal there is a change in the knowledge students have regarding the possible strategies that can serve as a means of integrating EfS. Still, it is an insignificant change since L3 is the most representative both at the beginning and at the end of the process, and the change produced between the two phases is slight. The increase seen in L4 is more striking. Similar studies conducted warn those changes are usually short-term [60] and of an intentional nature. Pre-service teachers therefore need continuous learning and training that emphasise the development of global and structural but flexible methodological strategies that help train citizens who think critically and are committed to action in the socio-ecological field [66].

\section{Conclusions}

This study focused on exploring the change in the perceptions of pre-service teachers who are doing a Master's Degree in Educational Research with regard to EfS. They participated in a training process in the subject Sustainability and Equity in the Ideal School, meant to train them in EfS and in the SDGs. In this research, several information-gathering tools were used for the different phases of the training process and an analysis system.

From a global perspective, the students' comments lead to the conclusion that after the training process, which focused on training in EfS, progress was observed in the three dimensions of analysis: EfS, the SDGs, and the methodological strategies for their integration. This could reflect an improvement in their training with respect to the role of sustainability in education.

Relevant changes were observed with respect to EfS since, at the end of the training process, the results reveal that more than two-thirds of the students have a perception of EfS that corresponds to the two most complex levels. In fact, at the beginning of the course, the results show there were no students that had a comprehensive and complex view of EfS. This is worth noting since students' practice in EfS is strongly affected by their own perceptions [67]. In light of the results, it is important to work towards a more complex understanding of future teachers' perceptions of EfS, since achieving a more sustainable world also requires a deep understanding of what sustainability means.

It must be stressed that the most significant changes refer to the dimension of the SDGs. At the beginning of the process, the results show that less than one-third of the students were familiar with them. However, at the end of the process, practically all the students indicated they knew them, as is observed in their comments in the UIs analysed. The SDGs represent interconnected knowledge that must provide answers to socio-environmental challenges and must be integrated into the area of education. They must be included in the classroom by means of transformative methodological strategies [5]. Moreover, involving students in world problems addressed in the SDGs benefits them with regard to understanding objectives and acquiring problem-solving skills [24]. The study of the SDGs should be included in training processes, since they are a way of accessing the complexity of EfS. However, their incorporation at the curricular level still requires thought processes and syllabi will need to be reorganized.

The least significant changes occurred in the methodological strategies dimension. The results at the beginning of the course showed the students already had previous knowledge of how they could integrate sustainability into their teaching practice, although they were mainly focused 
on resources and not on global and transformative strategies like problem-based learning, social and environmental problem solving, problem-based approaches supported by real- life projects, service-learning, calculation of carbon footprint, etc. [9], and they did it spontaneously or intuitively. This denotes it is key in pre-service teacher training to put more emphasis on global strategies in which students integrate previously acquired knowledge with regard to resources and activities to work on EfS in their future teaching practice. As other studies show, the strategies teachers use to integrate EfS is usually limited [9].

On a different note, the analysis conducted reveals how, in all the dimensions, cooperative work has a clear impact on the development of students' perceptions and knowledge. During the group work, they discussed and questioned both their initial ideas and the information put to use during the process. This contributed to progressing towards more complex levels.

The study also presented a series of limitations inherent to its nature. On the one hand, this particular research study was performed in a very specific context and is therefore not generalisable. On the other hand, the reduced number of participants resulted in a limited number of UIs, and limited information was hence obtained. Still, it does provide a system of analysis that is appropriate in the current research context, both in terms of dimensions and levels. A greater number of participants in future research as well as comparisons with other contexts would improve the analysis system.

As can be observed in the results, the short duration of the training process did not encourage the consolidation of new knowledge. A significant development of ideas implies the need for longer processes in time that, amongst other things, facilitate comparison with reality [68]. However, the results obtained reveal the path taken and the strategies used are appropriate to promote change.

To conclude, training student teachers in EfS is of a strategic nature when it comes to incorporating EfS into society [51]. Their training will be reflected in how they educate future generations. Education professionals also play a crucial role in transforming schools and society. However, integrating EfS into their training is complicated because there are different ideas about what it means and how to integrate it into teacher training [7]. According to previous studies [20,50,59], the courses and programmes that focus on Education for Sustainability improve the knowledge, training, and interest of the students with regard to EfS and influence their perceptions of how to teach [60]. It is therefore essential to encourage the implementation of this kind of programmes in pre-service teacher training as well as research studies on the impact of those courses in teacher training.

Author Contributions: Conceptualization, E.G.-G; P.A. and R.J.-F.; methodology, E.G.-G. and P.A.; writing-review and editing, E.G.G.; R.J.-F. and P.A.; investigation, resources, visualization, and validation E.G.-G., and P.A.; data curation, writing-original draft preparation, and project administration, E.G.-G. All authors have read and agreed to the published version of the manuscript.

Funding: This research received no external funding.

Acknowledgments: The authors gratefully acknowledge the support of the "Desarrollo Profesional del docente" Research Group of the Universidad de Cádiz.

Conflicts of Interest: The authors declare no conflict of interest.

\section{References}

1. Meira, P. De los Objetivos de Desarrollo del Milenio a los Objetivos para el Desarrollo Sostenible: El rol socialmente controvertido de la educación ambiental. Educ. Soc. Rev. Interv. Socioeduc. 2015, $61,58-73$.

2. UNESCO Education for Sustainable Development Goals: Learning Objectives; UNESCO: Paris, France, 2017.

3. Bybee, R. Planet Earth in crisis: How should science educators respond? Am. Biol. Teach. 1991, 53, 146-153. [CrossRef]

4. Leal Filho, W.; Raath, S.; Lazzarini, B.; Vargas, V.R.; de Souza, L.; Anholon, R.; Quelhas, O.L.G.; Haddad, R.; Klavins, M.; Orlovic, V.L. The role of transformation in learning and education for sustainability. J. Clean. Prod. 2018, 199, 286-295. [CrossRef] 
5. Odell, V.; Molthan-Hill, P.; Martin, S.; Sterling, S. Transformative education to address all sustainable development goals. In Encyclopedia of the UN Sustainable Development Goals; Leal Filho, W., Ed.; Springer Nature Switzerland AG 2019; Springer: Cham, Switzerland, 2020; pp. 905-916. ISBN 9783319699028.

6. García-González, E.; Jiménez-Fontana, R.; Azcárate, P. The training of future education professionals from the perspective of sustainability: A formative experience. In Proceedings of the INTED2017, Valencia, Spain, 6-8 March 2017; pp. 8572-8579.

7. Valderrama-Hernández, R.; Sánchez-Carracedo, F.; Alcántara Rubio, L.; Limón-Domínguez, D. Methodology to analyze the effectiveness of ESD in a higher degree in education. A case study. Sustainability 2020, 12, 222. [CrossRef]

8. Dlouhá, J.; Heras, R.; Mulà, I.; Salgado, F.P.; Henderson, L. Competences to address SDGs in higher education-a reflection on the equilibrium between systemic and personal approaches to achieve transformative action. Sustainability 2019, 11, 3664. [CrossRef]

9. García-González, E.; Jiménez-Fontana, R.; Goded, P.A. Approaches to teaching and learning for sustainability: Characterizing students' perceptions. J. Clean. Prod. 2020, 274, 122928. [CrossRef]

10. Aznar, P.; Ull, M.Á.; Martínez Agut, M.D.P.; Piñero Guillamany, A. Competencias básicas para la sostenibilidad: Un análisis desde el diálogo disciplinar. Bordon 2014, 66, 13-27.

11. Cebrián, G.; Junyent, M. Competencies in Education for Sustainable Development: Exploring the Student Teachers' Views. Sustainability 2015, 7, 2768-2786. [CrossRef]

12. Anyolo, E.O.; Kärkkäinen, S.; Keinonen, T. Implementing Education for Sustainable Development in Namibia: School Teachers' Perceptions and Teaching Practices. J. Teach. Educ. Sustain. 2018, 20, 64-81. [CrossRef]

13. Calafell, G.; Bonil, J. Identificación y caracterización de las concepciones de medio ambiente de un grupo de profesionales de la educación ambiental. Enseñanza Cienc. 2014, 32, 205-225.

14. Flores, R.C. Representaciones sociales del medio ambiente. Perf. Educ. 2008, 30, 33-62.

15. Albareda-Tiana, S.; Vidal-Raméntol, S.; Fernández-Morilla, M. Implementing the sustainable development goals at University level. Int. J. Sustain. High. Educ. 2018, 19, 473-497. [CrossRef]

16. Sandri, O. What do we mean by 'pedagogy' in sustainability education? Teach. High. Educ. 2020, 1-16. [CrossRef]

17. Sterling, S. Whole Systems Thinking as a Basic for Paradigm Change in Education: Explorations in the Context of Sustainability. Ph.D. Thesis, University of Barth, Bath, UK, 2003.

18. United Nations Transforming Our World: The 2030 Agenda for Sustainable Development. 2015. Available online: https://sustainabledevelopment.un.org/post2015/transformingourworld (accessed on 1 June 2020).

19. Gómez Gil, C. Objetivos de Desarrollo Sostenible (ODS): Una revisión crítica. Pap. Relac. Ecosoc. Cambio Glob. 2017, 140, 107-118.

20. Albareda-Tiana, S.; García-González, E.; Jiménez-Fontana, R.; Solís-Espallargas, C. Implementing Pedagogical Approaches for ESD in Initial Teacher Training at Spanish Universities. Sustainability 2019, 11, 4927. [CrossRef]

21. Zamora-Polo, F.; Sánchez-Martín, J.; Corrales-Serrano, M.; Espejo-Antúnez, L. What do university students know about sustainable development goals? A realistic approach to the reception of this UN program amongst the youth population. Sustainability 2019, 11, 3533. [CrossRef]

22. Jiménez-Fontana, R.; García-González, E.; Navarrete, A. The need to build the concept of Environment within the framework of Sustainable Development Goals. In Teaching and Sustainable Development; Leal Filho, W., Lange Salvia, A., Frankenberger, F., Eds.; Edward Elgar Publishing Inc.: Cham, Switzerland, 2017.

23. UNESCO. Education for Sustainable Development: Sourcebook; United Nations Educational: Paris, France, 2012; Available online: https://sustainabledevelopment.un.org/index.php?page=view\&type=400\&nr=926\&menu= 1515 (accessed on 6 April 2020).

24. Joseph, C.; Said, R. Student Engagement: Catalyst to Achieve the Sustainable Development Goal. In Quality Education. Encyclopedia of the UN Sustainable Development Goals; Leal Filho, W., Azul, A., Brandli, L., Özuyar, P., Wall, T., Eds.; Springer International Publishing: Cham, Switzerland, 2019; pp. 812-820.

25. Evans, N.; Ferreira, J.A. What does the research evidence base tell us about the use and impact of sustainability pedagogies in initial teacher education? Environ. Educ. Res. 2019, 26, 27-42. [CrossRef]

26. García-González, E.; Jiménez-Fontana, R.; Azcárate, P.; Cardeñoso, J.M. Inclusion of Sustainability in University Classrooms through Methodology. In Handbook of Theory and Practice of Sustainable Development in Higher Education; Leal Filho, W., Brandli, L., Newman, J., Castro, P., Eds.; Springer International Publishing: Cham, Switzerland, 2017; pp. 3-19. ISBN 978-3-319-47867-8. 
27. Zamora-Polo, F.; Sánchez-Martín, J. Teaching for a Better World. Sustainability and Sustainable Development Goals in the Construction of a Change-Maker University. Sustainability 2019, 11, 4224. [CrossRef]

28. Brandt, J.-O.; Barth, M.; Merritt, E.; Hale, A. A matter of connection: The 4 Cs of learning in pre-service teacher education for sustainability. J. Clean. Prod. 2020, 279, 123749. [CrossRef]

29. Svanström, M.; Lozano-García, F.J.; Rowe, D. Learning outcomes for sustainable development in higher education. Int. J. Sustain. High. Educ. 2008, 9, 339-351. [CrossRef]

30. Denzin, N.K.; Lincoln, Y.S. Introducción general. La investigación cualitativa como disciplina y como práctica. In El Campo De La Investigación Cualitativa; Denzin, N.K., Lincoln, Y.S., Eds.; Gedisa: Barcelona, Spain, 2011; pp. 43-116.

31. Kioupi, V.; Voulvoulis, N. Education for Sustainable Development: A Systemic Framework for Connecting the SDGs to Educational Outcomes. Sustainability 2019, 11, 6104. [CrossRef]

32. Lozano, R.; Merrill, M.; Sammalisto, K.; Ceulemans, K.; Lozano, F. Connecting Competences and Pedagogical Approaches for Sustainable Development in Higher Education: A Literature Review and Framework Proposal. Sustainability 2017, 9, 1889. [CrossRef]

33. García-González, E.; Jiménez-Fontana, R.; Azcárate, P. HAMS: A tool for the analyses of methodological activity of university professors from the principles of sustainability and complexity. Espacios 2018, 39, 28.

34. Jabareen, Y. A new conceptual framework for sustainable development. Environ. Dev. Sustain. 2008, 10, 179-192. [CrossRef]

35. Meadows, D.H.; Meadows, D.L.; Randers, J. The Limits to Growth; Universe Books: New York, NY, USA, 1972.

36. Carew, A.L.; Mitchell, C.A. Characterizing undergraduate engineering students' understanding of sustainability. Eur. J. Eng. Educ. 2002, 27, 349-361. [CrossRef]

37. Koehler, D.A.; Hecht, A.D. Sustainability, well being, and environmental protection: Perspectives and recommendations from an Environmental Protection Agency forum. Sustain. Sci. Pract. Policy 2006, 2, $22-28$. [CrossRef]

38. UNESCO United Nations Decade of Education for Sustainable Development 2005-2014: Draft International Implementation Scheme; Paris, France. 2004. Available online: https://unesdoc.unesco.org/ark:/48223/ pf0000139023_eng (accessed on 25 May 2020).

39. Cotton, D.; Winter, J. 'It's Not Just Bits of Paper and Light Bulbs': A Review of Sustainability Pedagogies and their Potential for Use in Higher Education. In Sustainability Education: Perspectives and Practice across Higher Education; Jones, P., Selby, D., Sterling, S., Eds.; Earthscan: London, UK, 2010; pp. 39-54.

40. Sterling, S. The Future Fit Framework: An Introductory Guide to Teaching and Learning for Sustainability in HE (Guide). J. Educ. Sustain. Dev. 2013, 7, 134-135. [CrossRef]

41. Tejedor, G.; Segal, J.; Barrón, Á.; Fernández-Morilla, M.; Fuertes, M.T.; Ruiz-Morales, J.; Guitérrez, I.; García-González, E.; Aramburuzabala, P.; Hernández, A. Didactic Strategies to Promote Competencies in Sustainability. Sustainability 2019, 11, 2086. [CrossRef]

42. Saura, P.; Hernández, M.A. La evolución del concepto de sostenibilidad y su incidencia en la Educación Ambiental. Teoría Educ. 2008, 20, 179-204.

43. Kagawa, F. Dissonance in students' perceptions of sustainable development and sustainability. Int. J. Sustain. High. Educ. 2007, 8, 317-338. [CrossRef]

44. Sureda-Negre, J.; Oliver-Trobat, M.; Catalan-Fernändez, A.; Comas-Forgas, R. Environmental education for sustainability in the curriculum of primary teacher training in Spain. Int. Res. Geogr. Environ. Educ. 2014, 23, 281-293. [CrossRef]

45. UNESCO Guidelines and Recommendations for Reorienting Teacher Education to Address Sustainability; Technical Paper No. 2 October 2005; Section for Education for Sustainable Development: Paris, France, 2005.

46. UNESCO. El futuro que queremos. In Proceedings of the Conferencia de las Naciones Unidas sobre el Desarrollo Sostenible, Río +20, Río de Janeiro, Brasil, 20-22 June 2012.

47. Dimenäs, J.; Alexandersson, M. Crossing disciplinary borders: Perspectives on learning about sustainable development. J. Teach. Educ. Sustain. 2012, 14, 5-19. [CrossRef]

48. Elkington, J. Enter the triple bottom line. In The Triple Bottom Line: Does it All Add Up? Earthscan: London, UK, 2013; pp. 23-38.

49. Zeegers, Y.; Clark, I.F. Students' perceptions of education for sustainable development. Int. J. Sustain. High. Educ. 2014, 15, 242-253. [CrossRef] 
50. Mifsud, M.C. Student Perceptions on the First Masters in Education for Sustainable Development in Malta. In Transformative Approaches to Sustainable Development; Leal Filho, W., Ed.; Springer International Publishing Switzerland: Cham, Switzerland, 2015; pp. 271-287. ISBN 978-3-319-08836-5.

51. Kieu, T.K.; Singer, J.; Gannon, T.J. Education for sustainable development in Vietnam: Lessons learned from teacher education. Int. J. Sustain. High. Educ. 2016, 17, 853-874. [CrossRef]

52. Tilbury, D. Environmental Education for Sustainability: Defining the new focus of environmental education in the 1990s. Environ. Educ. Res. 1995, 1, 195-212. [CrossRef]

53. Shulla, K.; Filho, W.L.; Lardjane, S.; Sommer, J.H.; Borgemeister, C. Sustainable development education in the context of the 2030 Agenda for sustainable development. Int. J. Sustain. Dev. World Ecol. 2020, 27, 458-468. [CrossRef]

54. Leal Filho, W.; Tripathi, S.T.; Salgueirinho Osório, J.B.; Giné-Garriga, R.; Orlovic, V.; Willats, J. Using the Sustainable Development Goals Towards a Better Understanding of Sustainability Challenges. Int. J. Sustain. Dev. World Ecol. 2019, 26, 179-190. [CrossRef]

55. Leal Filho, W.; Shiel, C.; Paço, A.; Mifsud, M.; Ávila, L.V.; Brandli, L.L.; Molthan-Hill, P.; Pace, P.; Azeiteiro, U.M.; Vargas, V.R.; et al. Sustainable Development Goals and sustainability teaching at universities: Falling behind or getting ahead of the pack? J. Clean. Prod. 2019, 232, 285-294. [CrossRef]

56. Ruiz-Mallén, I.; Heras, M. What sustainability? Higher Education Institutions' pathways to reach the Agenda 2030 goals. Sustainability 2020, 12, 1290. [CrossRef]

57. Aleixo, A.M.; Azeiteiro, U.M.; Leal, S. Are the sustainable development goals being implemented in the Portuguese higher education formative offer? Int. J. Sustain. High. Educ. 2020, 21, 336-352. [CrossRef]

58. Lai, Y.C.; Peng, L.H. Effective teaching and activities of excellent teachers for the sustainable development of higher design education. Sustainability 2020, 12, 28. [CrossRef]

59. Nousheen, A.; Yousuf Zai, S.A.; Waseem, M.; Khan, S.A. Education for sustainable development (ESD): Effects of sustainability education on pre-service teachers' attitude towards sustainable development (SD). J. Clean. Prod. 2020, 250, 119537. [CrossRef]

60. Andersson, K. Starting the pluralistic tradition of teaching? Effects of education for sustainable development (ESD) on pre-service teachers' views on teaching about sustainable development. Environ. Educ. Res. 2017, 23, 436-449. [CrossRef]

61. Weitz, N.; Carlsen, H.; Nilsson, M.; Skånberg, K. Towards systemic and contextual priority setting for implementing the 2030 agenda. Sustain. Sci. 2018, 13, 531-548. [CrossRef] [PubMed]

62. Cuesta, J.; Azcarate, P.; Cardeñoso, J.M. The Role of Reflection and Collaboration in the Evolution of a Group of Novice Secondary Education Science Teachers. Aust. J. Teach. Educ. 2016, 41, 136-152. [CrossRef]

63. John, F. Education for Sustainability: Reorientating Australian schools for a sustainable future. Tela Environ. Econ. Soc. 2001, 8, 1-36.

64. Taylor, N.; Nathan, S.; Coll, R.K. Education for sustainability in regional New South Wales, Australia: An exploratory study of some teachers' perceptions. Int. Res. Geogr. Environ. Educ. 2003, 12, 291-311. [CrossRef]

65. Trott, C.D. Children's constructive climate change engagement: Empowering awareness, agency, and action. Environ. Educ. Res. 2019, 26, 532-554. [CrossRef]

66. Lasen, M.; Skamp, K.; Simoncini, K. Teacher Perceptions and Self-Reported Practices of Education for Sustainability in the Early Years of Primary School: An Australian Case Study. Int. J. Early Child. 2017, 49, 391-410. [CrossRef]

67. To Khuyen, N.T.; Van Bien, N.; Lin, P.L.; Lin, J.; Chang, C.Y. Measuring teachers' perceptions to sustain STEM education development. Sustainabilty. 2020, 12, 1531. [CrossRef]

68. Lengyel, A.; Szőke, S.; Kovács, S.; Dávid, L.D.; Bácsné Bába, É.; Müller, A. Assessing the essential pre-conditions of an authentic sustainability curriculum. Int. J. Sustain. High. Educ. 2019, 20, 309-340. [CrossRef]

(C) 2020 by the authors. Licensee MDPI, Basel, Switzerland. This article is an open access article distributed under the terms and conditions of the Creative Commons Attribution (CC BY) license (http://creativecommons.org/licenses/by/4.0/). 